\title{
ANALYSIS OF CUSTOMER SATISFACTION ON QUALITY OF JAKARTA CORRIDOR MRT (MASS RAPID TRANSIT) SERVICE 1 (LEBAKBULUS STATION - BUNDARAN HI)
}

\author{
Ari Hesti, PURNOMO \\ Faculty of Engineering, University Mercu Buana Jakarta, Indonesia \\ arihesti7@gmail.com \\ Amar, MUFHIDIN \\ Faculty of Engineering, University Mercu Buana Jakarta, Indonesia \\ amarmufhidin@gmail.com
}

\begin{abstract}
Seeing the very high mobility behavior of the Jakarta people and difficult to avoid congestion, it is appropriate, a solution that invites people to move from private vehicles to mass transportation modes such as the Jakarta MRT. The transportation service industry is an interesting sector to observe because Jakarta MRT is relatively new transportation in Jakarta. This study aims to determine the level of passenger satisfaction with the quality of Jakarta Corridor 1 MRT services (Lebak bulus Station - HI Roundabout) reviewed using the questionnaire method, using 100 respondents taken randomly from Lebak Bulus to the $\mathrm{HI}$ Roundabout and vice versa. To get the results of customer satisfaction required data on the average rating of respondents and the results obtained an average value above 3 and included in the category of very satisfied according to the CSI table. To get data that needs to be a priority to be improved and data that needs to be maintained the level of service quality needs to be tested using the Cartesian diagram of the importance- performance method and the results of data that become priorities for improvement are safety aspects at trains and stations as well as courtesy of officers. To test the results of the analysis conducted a validity test using the bivariate correlation method to measure the validity and invalidity of the data with a significance value of $1 \%$ and $R$ tables obtained at 0.258 and $100 \%$ validity results (all valid data), reliability testing to measure the level of consistency of respondents in filling out the questionnaire from the SPSS program counting process gets the result that the questionnaire has a high level of consistency.
\end{abstract}

Keywords: Satisfaction Analysis, MRT Jakarta Service Level

\section{INTRODUCTION}

PT MRT (mass rapid transit) is one of the companies engaged in inland transportation services. The transportation service industry is an interesting sector to observe because Jakarta MRT is relatively new transportation in Jakarta. Jakarta MRT has advantages in the right time efficiency, clean and integrated with Trans Jakarta, which greatly facilitates the community to meet the needs of moving places in a short time.

Jakarta MRT, can accommodate 130,000 passengers per day (results of the 2017 survey) enough to reduce the volume of Jakarta's road density, has 16 Ratangga series (the name of the MRT train series). One Ratangga has 6 train lines, within 5 minutes the ratangga will arrive at each station (at a busy time). The Ratangga series has a speed of $80 \mathrm{~km} /$ hour, on the elevated line and $100 \mathrm{~km} /$ hour on the underground line, and records a 
time of 30 minutes, from the Lebak Bulus- Bundaran HI station. MRT Jakarta has operational time from 05.00-24.00 WIB, every day. (www.jakartamrt.co.id-infographic 2018)

The method used in this research is quantitative and qualitative approaches. Where the quantitative approach in this study was taken from primary and secondary data. The primary data is taken by taking data directly to the subject variable with a questionnaire or questionnaire method. While secondary data is taken from data from related parties, namely data from PT. Jakarta MRT, Ministry of Transportation, Statistics Indonesia, and others.

\section{Library REVIEW}

Satisfaction has a harmonious relationship with and expectations. Someone will feel satisfied if the expectations or performance, equal to or exceed the performance that actually happened, and vice versa. The concept of customer satisfaction has an understanding of the level of satisfaction of a customer or service user after comparing the reality of the performance or perceived results with expectations and perceptions of the service Kortel, P., (1997).

According to Nasution, M. (1996) Transportation is defined as the removal of goods and people from the place of origin to the destination. So with these activities, there are three things, namely the load being transported, the availability of vehicles as a means of transport, and there are roads that can be traversed. The transportation process is a movement from the place of origin where the transport activity begins, to the destination where the transport activity ends. And according to Rustian, K. (2003). Transportation is the activity of moving goods (cargo) and passengers from one place to another.

Lovelock, C., \& Patterson, P. (2015). Stating that the service is "the action or performance offered by one party to another party where there are economic activities that create and provide benefits to customers at certain times and places".

Five main dimensions of Service Quality in Zeithaml, V. A., Bitner, M. J., \& Gremler, D. D. (2006). these are:

a. Reliability: the ability to provide services accurately and reliably.

b. Responsiveness: the desire to help customers and provide services quickly.

c. Guarantee: employee knowledge and friendliness to foster trust in customers.

d. Empathy: special attention given to customers.

Physical Proof: the appearance of physical facilities, equipment and service employees of a company cannot be separated from the five main dimensions, because in its operations the company must continue to improve the quality of service provided to customers. Service Quality is used as a measure of service that uses certain measurement scales, such as multiple-item scales.

Zeithaml, V. A., Berry, L. L., \& Parasuraman, A. (1996). "Satisfaction is the customer's evaluation of a product or service in terms of whether that product or services has met the customer's needs and expectation"

\section{RESEARCH METHODS}

\section{Research Location and Time}

Research on customer satisfaction analysis on the quality of Jakarta MRT services was conducted in corridor 1 (Lebak Bulus-Bundaran $\mathrm{HI}$ ), morning (07.00-10.00) \& afternoon (15.00-18.00), week date, November 10, 2019, \& Monday, November 11, 2019, with 100 
respondents.

\section{Determine the number of respondents (sample)}

To determine the number of respondents used a sampling method by considering the limitations of labor, time and cost in this study. The number of respondents is determined by the Slovin formula where:

$n=\frac{N}{1+N(e)^{2}}$

Where:

$\mathrm{n}=$ Stamp Number $\mathrm{N}=$ total population

$\mathrm{e}=$ Percentage of Allowance for Inaccuracy Due to Sample Mistakes that Can still be tolerated $10 \%$

\section{Testing validity}

Reliability is actually a tool to measure a questionnaire which is an indicator of a variable or constructs. A questionnaire is said to be reliable or reliable if a person's answers to questions are consistent or stable from time to time.

\section{Reliability Testing}

This test is carried out to obtain the correlation value between factors items 1-19 to the total assessment of service performance indicating the level of significance

/ valid.

For the reliability of a questionnaire, the decision-making conditions are taken first, that if:

Cronbach's Alpha> R table, then consistent.

Cronbach's Alpha $<\mathrm{R}$ table, then it's not consistent.

\section{Importance-Performance Analysis}

Importance-Performance Analysis (IPA) is a descriptive analysis technique that was introduced by John A. Martilla and John C. James in 1977. Importance Performance Analysis is an analysis technique used to identify what important performance factors should be demonstrated by an organization in meeting the satisfaction of service users (consumers).

The results of the assessment of the level of importance and the results of the performance assessment will be obtained by a calculation of the level of conformity between the level of importance and the level of implementation by the service provider. Conformity level is the result of a comparison between the performance score with the importance score, so this conformity level will determine the priority scale that will be used in handling factors that influence consumer satisfaction. The formula to find out the suitability level is. Suhendra, A., \& Prasetyanto, D. (2016).

$T_{k}=\frac{X}{Y} \times 100 \%$ 
With: = Conformance level of respondents

$X=$ Score assessment of the performance of service providers

$Y=$ Score assessment of the interests of service users (consumers)

\section{Customer Satisfaction Index (CSI)}

The Customer Satisfaction Index (CSI) is used to determine the level of customer/customer satisfaction of a company/service provider as a whole with an approach that considers the user's judgment of the performance of the service provider on the attributes measured. The interpretation of CSI values can be seen in Table. Suhendra, A., \& Prasetyanto, D. (2016).

To determine the value of the Customer Satisfaction Index (CSI) the following formula is needed:

$C S I=\frac{\sum_{i=1}^{P} W S i}{H S} X 100 \%$

Where: HS (highest Scale) $=$ The maximum scale used

\section{Calculation of Priority Levels}

Performance Analysis. Data grouping is divided into 4 quadrants, where: Iswari, I.

I. M., Wiranatha, A. A. S., \& Satriawan, I. K. (2015). To be able to translate the results of data analysis as evaluation material, improve service performance or still maintain performance in certain services, grouping the results of the 4 quadrant data analysis according to the Cartesian Diagram Important

theses related to this research.

\section{RESULTS AND DISCUSSION}

\section{Determine the Number of Respondents (Samples)}

Data on the number of Jakarta MRT daily peak transportation users is 79,287 people/day (source @mrtjkt instagram), so it can be entered into the formula as follows:

$n=\frac{79.287}{1+79.287(0,1)^{2}}=99,87$

Obtained $\mathrm{n}=99.87$ inhabitants, so that it rounded up to 100 inhabitants. In this study, it was concluded that 100 respondents would be sampled in the Jakarta Corridor 1 MRT transportation mode passenger (Lebak bulus-Bundaran $\mathrm{HI}$ )

\section{Test validity}

The $\mathrm{R}$ table value is obtained from the distribution table $\mathrm{R}$-Value of the significance table of $5 \%$ and $1 \%$ with the value of $\mathrm{N}=$ Number of respondents 100 and the significance value of $1 \%$, then the $\mathrm{R}$ table of 0.258 is obtained. 


\section{Tabel 1 Perhitungan R Tabel}

\begin{tabular}{|c|c|c|c|c|}
\hline \multicolumn{5}{|c|}{ Perhitungan R Tabel } \\
\hline $\mathrm{N}$ & $\mathrm{df}$ & alpha & t-tabel & r-tabel \\
\hline 100 & 98 & 0,01 & 2,626931 & 0,258521 \\
\hline
\end{tabular}

From the calculation results of the $R$ table above the results obtained are 0.258521 and rounded to 0.258 in order to facilitate the validity test. So from the input results on the SPSS program, the following results are obtained:

Table 2 SPSS Output Results for Validity Test Using Bivariate Correlation Analysis on Service Performance Factors

\begin{tabular}{|c|c|c|c|c|c|c|c|}
\hline $\begin{array}{c}\text { No. } \\
\text { Item }\end{array}$ & $\begin{array}{c}\mathrm{R} \\
\text { computes }\end{array}$ & $\mathrm{R}$ table & Description & $\begin{array}{c}\text { No. } \\
\text { Item }\end{array}$ & $\begin{array}{c}\mathrm{R} \\
\text { computes }\end{array}$ & $\mathrm{R}$ table & Description \\
\hline $\mathrm{i} 1$ & 0,608 & 0,258 & Valid & $\mathrm{i} 11$ & 0,673 & 0,258 & Valid \\
\hline $\mathrm{i} 2$ & 0,673 & 0,258 & Valid & $\mathrm{i} 12$ & 0,747 & 0,258 & Valid \\
\hline $\mathrm{i} 3$ & 0,795 & 0,258 & Valid & $\mathrm{i} 13$ & 0,843 & 0,258 & Valid \\
\hline i4 & 0,721 & 0,258 & Valid & $\mathrm{i} 14$ & 0,731 & 0,258 & Valid \\
\hline i5 & 0,608 & 0,258 & Valid & $\mathrm{i} 15$ & 0,827 & 0,258 & Valid \\
\hline i6 & 0,807 & 0,258 & Valid & $\mathrm{i} 16$ & 0,767 & 0,258 & Valid \\
\hline i7 & 0,732 & 0,258 & Valid & $\mathrm{i} 17$ & 0,82 & 0,258 & Valid \\
\hline i8 & 0,849 & 0,258 & Valid & $\mathrm{i} 18$ & 0,86 & 0,258 & Valid \\
\hline i9 & 0,804 & 0,258 & Valid & $\mathrm{i} 19$ & 0,869 & 0,258 & Valid \\
\hline i10 & 0,625 & 0,258 & Valid & & & & \\
\hline
\end{tabular}

From table 2 the results show that the correlation between items $1-19$ to the total assessment of service performance shows significance / valid

Table 3 Table of SPSS Output Results for Validity Test with Bivariate Correlation Analysis on the Level of Interest Factors

\begin{tabular}{|c|c|c|c|c|c|c|c|}
\hline $\begin{array}{c}\text { No. } \\
\text { Item }\end{array}$ & $\begin{array}{c}\mathrm{R} \\
\text { computes }\end{array}$ & $\mathrm{R}$ table & Description & $\begin{array}{c}\text { No. } \\
\text { Item }\end{array}$ & $\begin{array}{c}\mathrm{R} \\
\text { computes }\end{array}$ & $\mathrm{R}$ table & Description \\
\hline $\mathrm{i} 1$ & 0,647 & 0,258 & Valid & $\mathrm{i} 11$ & 0,674 & 0,258 & Valid \\
\hline $\mathrm{i} 2$ & 0,684 & 0,258 & Valid & $\mathrm{i} 12$ & 0,766 & 0,258 & Valid \\
\hline $\mathrm{i} 3$ & 0,786 & 0,258 & Valid & $\mathrm{i} 13$ & 0,849 & 0,258 & Valid \\
\hline $\mathrm{i} 4$ & 0,741 & 0,258 & Valid & $\mathrm{i} 14$ & 0,71 & 0,258 & Valid \\
\hline $\mathrm{i} 5$ & 0,57 & 0,258 & Valid & $\mathrm{i} 15$ & 0,791 & 0,258 & Valid \\
\hline $\mathrm{i} 6$ & 0,747 & 0,258 & Valid & $\mathrm{i} 16$ & 0,746 & 0,258 & Valid \\
\hline $\mathrm{i} 7$ & 0,777 & 0,258 & Valid & $\mathrm{i} 17$ & 0,722 & 0,258 & Valid \\
\hline $\mathrm{i} 8$ & 0,762 & 0,258 & Valid & $\mathrm{i} 18$ & 0,877 & 0,258 & Valid \\
\hline $\mathrm{i} 9$ & 0,782 & 0,258 & Valid & $\mathrm{i} 19$ & 0,878 & 0,258 & Valid \\
\hline $\mathrm{i} 10$ & 0,655 & 0,258 & Valid & & & & \\
\hline
\end{tabular}

From table 3 the results show that the correlations between items 1-19 to the total importance rating indicate significance / valid. 


\section{Reliability test}

item factor input is done from 1-19 to the score given by the respondent for service performance in SPSS so that it gets output like the following:

\begin{tabular}{|c|c|c|}
\hline \multicolumn{3}{|c|}{ Tangibles Statistics } \\
\hline $\begin{array}{c}\text { Cronbach's } \\
\text { Alpha }\end{array}$ & \begin{tabular}{|c|} 
Cronbach's \\
Alpha Based \\
on \\
Standardized \\
Items
\end{tabular} & $\mathrm{N}$ of Items \\
\hline .712 & .713 & 5 \\
\hline \multicolumn{3}{|c|}{ Reliability Statistics } \\
\hline $\begin{array}{c}\text { Cronbach's } \\
\text { Alpha }\end{array}$ & \begin{tabular}{|c|} 
Cronbach's \\
Alpha Based \\
on \\
Standardized \\
Items \\
\end{tabular} & $\mathrm{N}$ of Items \\
\hline .809 & .810 & 4 \\
\hline \multicolumn{3}{|c|}{ Responsiveness Statistics } \\
\hline $\begin{array}{c}\text { Cronbach's } \\
\text { Alpha }\end{array}$ & \begin{tabular}{|c|} 
Cronbach's \\
Alpha Based \\
on \\
Standardized \\
Items \\
\end{tabular} & $\mathrm{N}$ of Items \\
\hline .700 & .701 & 4 \\
\hline \multicolumn{3}{|c|}{ Assurance Statistics } \\
\hline $\begin{array}{c}\text { Cronbach's } \\
\text { Alpha }\end{array}$ & \begin{tabular}{|c|} 
Cronbach's \\
Alpha Based \\
on \\
Standardized \\
Items \\
\end{tabular} & $\mathrm{N}$ of Items \\
\hline .792 & .794 & 4 \\
\hline \multicolumn{3}{|c|}{ Empathy Statistics } \\
\hline $\begin{array}{c}\text { Cronbach's } \\
\text { Alpha }\end{array}$ & \begin{tabular}{|c|} 
Cronbach's \\
Alpha Based \\
on \\
Standardized \\
Items \\
\end{tabular} & $\mathrm{N}$ of Items \\
\hline .662 & .663 & 2 \\
\hline
\end{tabular}

Figure 1 Results of SPSS Output Testing Reliability for Interest Level Factors

Viewed from Figure 1 that the value of Cronbach's Alpha as $R$ table is 0.258 so that Cronbach's Alpha> R table. And prove that all variables identified "reliable/consistent".

Then the item factor input is done from 1-19 to the score given by the respondent for the importance of the service in SPSS so that it gets output as follows: 


\begin{tabular}{|c|c|c|}
\hline Tangibles & & \\
\hline $\begin{array}{c}\text { Cronbach's } \\
\text { Alpha }\end{array}$ & $\begin{array}{c}\text { Cronbach's } \\
\text { Alpha Based } \\
\text { on } \\
\text { Standardized } \\
\text { Items }\end{array}$ & $\mathrm{N}$ of Items \\
\hline .719 & .719 & 5 \\
\hline \multicolumn{3}{|l|}{ Reliability } \\
\hline $\begin{array}{c}\text { Cronbach's } \\
\text { Alpha }\end{array}$ & \begin{tabular}{|} 
Cronbach's \\
Alpha Based \\
on \\
Standardized \\
Items
\end{tabular} & $\mathrm{N}$ of Items \\
\hline .766 & .767 & 4 \\
\hline \multicolumn{3}{|l|}{ Responsiven } \\
\hline $\begin{array}{c}\text { Cronbach's } \\
\text { Alpha }\end{array}$ & \begin{tabular}{|} 
Cronbach's \\
Alpha Based \\
on \\
Standardized \\
Items \\
\end{tabular} & $\mathrm{N}$ of Items \\
\hline .723 & .724 & 4 \\
\hline \multicolumn{3}{|l|}{ Assurance } \\
\hline $\begin{array}{c}\text { Cronbach's } \\
\text { Alpha }\end{array}$ & \begin{tabular}{|} 
Cronbach's \\
Alpha Based \\
on \\
Standardized \\
Items
\end{tabular} & $\mathrm{N}$ of Items \\
\hline .725 & .728 & 4 \\
\hline \multicolumn{3}{|l|}{ Empathy } \\
\hline $\begin{array}{c}\text { Cronbach's } \\
\text { Alpha }\end{array}$ & \begin{tabular}{|} 
Cronbach's \\
Alpha Based \\
on \\
Standardized \\
Items \\
\end{tabular} & $\mathrm{N}$ of Items \\
\hline .701 & .701 & 2 \\
\hline
\end{tabular}

Figure 2 Results of SPSS Output for Reliability Testing for Importance Factors

Judging from Figure 2, the value of Cronbach's Alpha as $\mathrm{R}$ table is 0.258 so that Cronbach's Alpha> R table. And prove that all variables identified "reliable/consistent".

\section{Analysis of Customer Satisfaction}

From the results of the calculation of the questionnaire data that had been distributed, in the adjusted places, the average results obtained by extracting questionnaires 1-4 obtained the following results. 
Table 4 Calculation of average performance and level of importance based on dimensions of service elements

\begin{tabular}{|c|l|c|c|}
\hline No & \multicolumn{1}{|c|}{$\begin{array}{c}\text { Elements affecting } \\
\text { passenger } \\
\text { satisfaction }\end{array}$} & $\begin{array}{c}\text { Service } \\
\text { Performance }\end{array}$ & $\begin{array}{c}\text { Level of } \\
\text { Interest }\end{array}$ \\
\hline A & Tangible & 3,17 & 3,36 \\
\hline B & Reliability & 3,24 & 3,27 \\
\hline C & Responsiveness & 3,21 & 3,34 \\
\hline D & Assurance & 3,19 & 3,27 \\
\hline E & Emphty & 3,17 & 3,83 \\
\hline & Average & 3.2 & 3.41 \\
\hline
\end{tabular}

It is seen from table 4 that respondents' ratings get ratings that are very satisfied.

\section{Calculation of Priority Levels}

Iswari, I. I. M., Wiranatha, A. A. S., \& Satriawan, I. K. (2015). To be able to translate the results of data analysis as evaluation material, improve service performance or continue to maintain performance in certain services, grouping the results of 4 quadrant data analysis according to the Cartesian Diagram Important Performance Analysis. Data grouping is divided into 4 quadrants, where:

a. Quadrant A

The data included in this quadrant has an unsatisfactory service performance assessment while the act of interest is very high, so it becomes the company's top priority to evaluate or improve the elements included in this quadrant.

b. Quadrant B

The data included in this quadrant have a satisfactory service performance assessment and a very high level of importance, so the elements included in this quadrant need to be maintained by the company.

c. Quadrant C

The data included in this quadrant has an unsatisfactory service performance evaluation and a low level of importance, so this service has a low priority for improvement or evaluation.

d. Quadrant D

The data included in this quadrant have a satisfactory service performance assessment but its importance is low, so companies need to reduce services in this quadrant to minimize the use of funds because this quadrant has priorities to reduce. 
The average value obtained is the middle value or the value of the divisor on the Cartesian Diagram Important Performance Analysis Below.

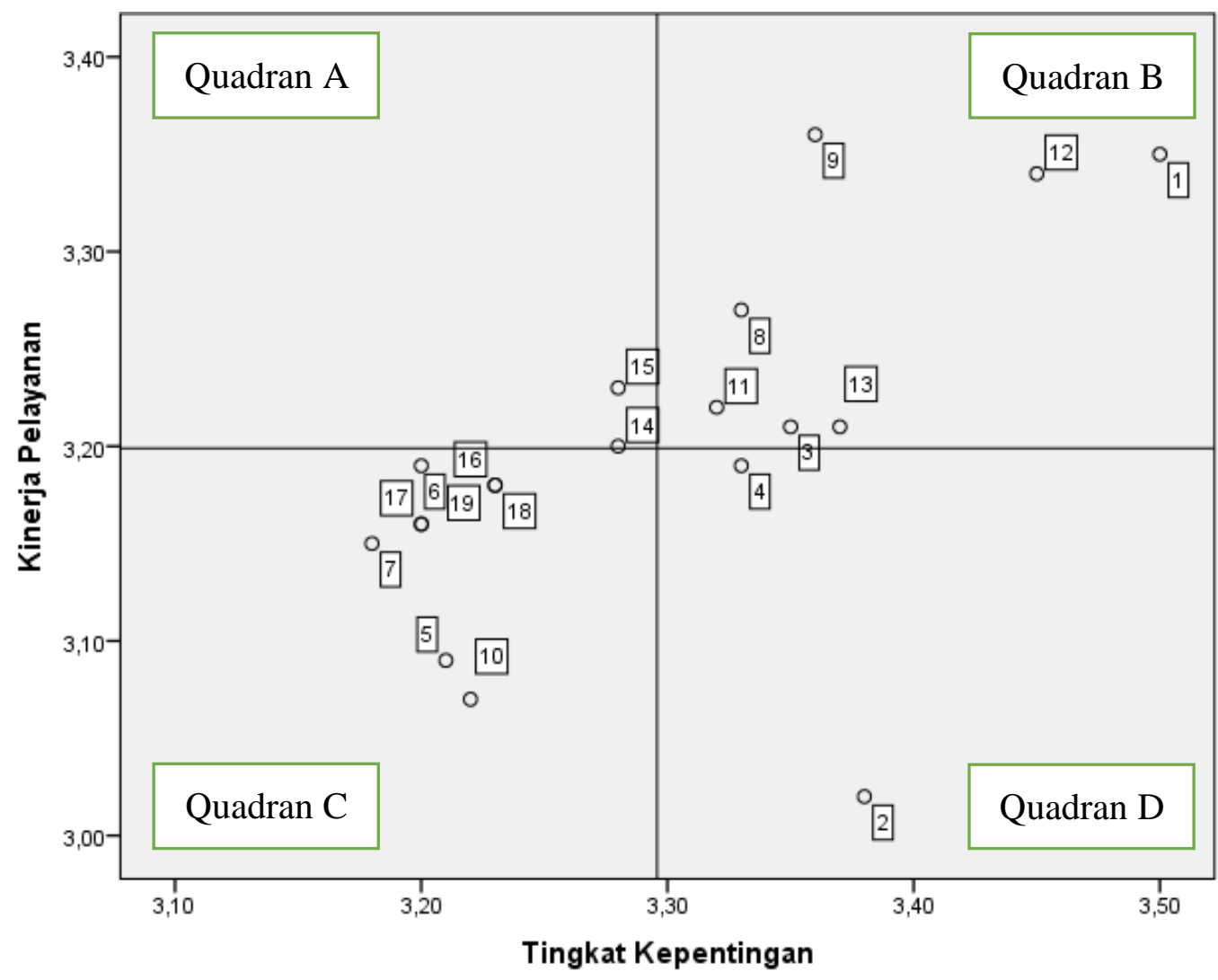

Figure 3 Cartesian Diagram Important Performance Analysis

\section{CONCLUSIONS}

Based on the results of the analysis of calculations performed on facilities and infrastructure contained in the Jakarta MRT public transport mode route 1 (Lebak Bulus - HI Roundabout), the conclusion is that:

1. The level of service is categorized as a high priority because it is unsatisfactory but has a high level of importance so it needs to be improved (quadrant A) including evaluation in terms of safety on trains and stations, and the courtesy of officers.

2. The level of service categorized needs to be maintained (quadrant B) including the condition of carriage cleanliness, completeness of the facilities at the train and station, certainty of departure schedules, punctuality of arriving and departing ratangga, speed of response of officers, certainty of delivery of information in the car and certainty of delivery of information in the Jakarta MRT station.

3. The level of service is categorized as low priority because service performance is not affected much on the level of satisfaction (quadrant $\mathrm{C}$ ) including ticket prices, ease of purchasing tickets, ease of obtaining information, follow-up complaints, the honesty of officers, skills of officers, caring officers and hospitality of officers.

4. The level of service is categorized as a priority to reduce its performance in order to minimize costs (quadrant D) including the cleanliness conditions of the MRT station and the neatness of the MRT officers. 


\section{Suggestion}

From the research results obtained that have received a high enough value, it is recommended to evaluate the services contained in quadrant $A$, including increasing security patrols in stations and ratangga cars to minimize crime in the Jakarta MRT environment and create a sense of security on trains and stations.

Providing counsel Bing and training for Jakarta MRT officers and increasing the politeness of Jakarta MRT officers.

\section{REFERENCE}

Anonim. www.jakartamrt.co.id. Jakarta : s.n., 2019.

Ghozali, I. Aplikasi Analisis dengan program SPSS. Semarang : Badan Penerbit Universitas Diponegoro, 2001.

Iswari, I. I. M., Wiranatha, A. A. S., \& Satriawan, I. K. ANALISIS KEPUASAN KONSUMEN TERHADAP KUALITAS PELAYANAN DAN JASA DENGAN MENGGUNAKAN METODE IMPORTANCE PERFORMANCE ANALYSIS (Studi Kasus di Restoran Warung Subak, Peguyangan Denpasar). Jurnal Rekayasa dan Manajemen Agroindustri, 3(3), 51-60. Bali : s.n., 2015.

KURNIAWAN, Safar Dwi and SETYAWAN, Antonius Ary. PENGUKURAN KESENJANGAN DIGITAL DI BANYUMAS UNTUK MENGETAHUI KESIAPAN MASYARAKAT DALAM MEMANFAATKAN SMART CITY. EDUSAINTEK. BANYUMAS : s.n., 2019.

Kotler, P., Keller, K. L., Ang, S. H., Tan, C. T., \& Leong, S. M. Marketingmanagement: an Asian perspective. 2018.

Lovelock, C., \& Patterson, P. Services marketing. Australia : s.n., 2015.

Nasution, M. Pengantar Manajemen. Jakarta : Djambatan, 1996.

Rustian, K. Ekonomi Transportasi. Jakarta : Ghalia Indonesia, 2003.

Suhendra, A., \& Prasetyanto, D. Kajian Tingkat Kepuasan Pengguna Trans Metro Bandung Koridor 2 Menggunakan Pendekatan Importance- Performance Analysis (Hal. 59-70). s.l. : RekaRacana, 2016.

Zeithaml, V. A., Bitner, M. J., \& Gremler, D. D. Service Marketing Integrating Custo. 2006.

Across, mer Focus. the Firm New York: MrGraw-Hill Education. Asia : s.n.

Zeithaml, V. A., Berry, L. L., \& Parasuraman, A. The behavioral consequences of service quality. Journal of marketing,60(2), 31-46. 1996. 